\title{
Doubled haploids as a material for biotechnological manipulation and as a modern tool for breeding oilseed rape (Brassica napus L.)
}

\author{
Teresa Cegielska-Taras ${ }^{1 *}$, LaurencJa SzaŁa ${ }^{1}$, Marcin MatuszczaK ${ }^{1}$, Danuta Babula-Skowrońska ${ }^{2}$, \\ KataRzyna MikoŁaJCZyK ${ }^{1}$, WiesŁaWa PoPŁaWska ${ }^{1}$, Katarzyna SoSNOWSKa ${ }^{1}$, BŁażeJ Hernacki ${ }^{1}$, \\ ANNA OLEJNIK ${ }^{1}$, IWONA BARTKOWIAK-BRODA ${ }^{1}$ \\ ${ }^{1}$ Plant Breeding and Acclimatization Institute - National Research Institute, Research Division in Poznań, Poland \\ ${ }^{2}$ Institute of Plant Genetics, Polish Academy of Sciences, Poznań, Poland \\ *Corresponding author: tceg@nico.ihar.poznan.pl
}

\begin{abstract}
Haploids and doubled haploids (DHs) have been produced in Brassica ssp. using anther or isolated microspore cultures. Since 1982, when Lichter developed a method of isolated microspores culture, this technique has been constantly improved and modified. Haploids and DH of Brassica napus have been extensively used in genetic studies, such as gene mapping, location of quantitative trait locus, marker/trait association studies, and genomics. Furthermore, the oilseed rape haploid induction technique can nowadays be efficiently combined with several other plant biotechnological techniques, enabling several novel breeding achievements, such as mutation breeding, the breeding of hybrid varieties, genetic transformation, and resynthesis of B. napus. The development and improvement of in vitro androgenesis of oilseed rape allowed $\mathrm{DH}$ populations to be obtained on a large scale. Today DH lines are used in the genetic analysis of quantitative traits and to analyze the impact of the environment on the yield and quality of the seeds. Currently, DH technology has become more efficient and hence can be widely applied in winter oilseed rape breeding. Additionally, DH technology is used to shorten the process of breeding new varieties. An open pollinated B. napus cv. Monolit (Plant Breeding Strzelce Ltd., Co.) is the first Polish winter oilseed rape variety obtained using DH technology. The breeding cycle of this variety is about four years shorter compared to a classical breeding program. The second Polish cultivar obtained using DH technology, cv. Brendy (Plant Breeding Smolice Ltd., Co.) was developed in a similarly short period. In the breeding of new oilseed rape hybrid varieties, homozygous restorer lines are also exploited. Our basic research used oilseed rape DH technology with a focus on improving the qualitative traits of oilseed rape and is presented here, based on the major researches conducted worldwide as well as on the results obtained at the Plant Breeding and Acclimatization Institute - National Research Institute in Poznań.
\end{abstract}

Key words: Brassica napus L., oilseed rape, doubled haploids, markers-assisted selection, gene mapping, transformation, breeding

Abbreviations
$\begin{array}{ll}\text { AFLP } & \text { - amplified fragment length polymorphism } \\ \text { CMS ogura } & \text { - cytoplasmic male sterility ogura } \\ \text { DH } & \text { - doubled haploid } \\ \text { ISSR } & \text { - inter-SSR amplification } \\ \text { MDE } & \text { - microspore-derived embryo } \\ \text { QTL } & \text { - quantitative trait locus } \\ \text { PCR } & \text { - polymerase chain reaction } \\ \text { RAPD } & \text { - random amplified polymorphic DNA }\end{array}$

\section{Introduction}

Oilseed rape (Brassica napus L.) is the third, after palm and soybean, most important source of vegetable oil in the world; it contributes significantly to the eco-

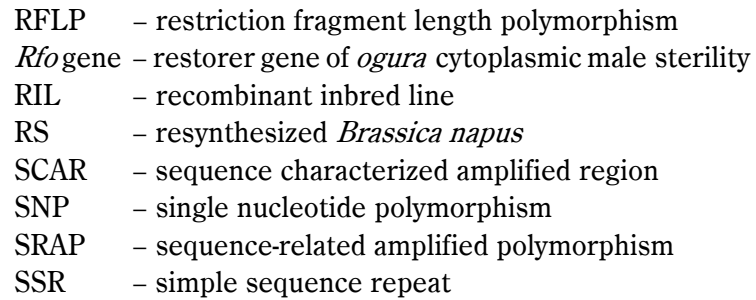

nomy of many countries. Due to its economic value and high performance in an in vitro culture, oilseed rape is considered as one of the most suitable species that can be improved through biotechnology techniques. One of 
the biotechnological methods most useful in basic researches and in plant breeding is androgenesis in vitro that aims at the development of haploids and doubled haploids (DH). Microspores isolated from the anthers of oilseed rape can be induced to develop into fully functional haploid embryos, instead of mature pollen grains. The ability of these cells to change their development process in response to environmental stimuli is an exceptional example of their totipotency.

The history of this method is almost a hundred years old. Since the first discovery of the spontaneous development of haploid plants in Datura stramonium in 1922 (Blakeslee et al., 1922), particularly after the discovery of in vitro androgenesis in anther cultures of Datura in 1964 (Guha and Maheshwari, 1964, 1966), the potential of haploids arose. Later, Zentkteler developed an in vitro production of Atropa belladonna L. haploid plants and in 1972 elaborated a method for obtaining embryos and plantlets from microspores in in vitro anther culture of Lycium halimifolium $\mathrm{Mu}, \mathrm{L}$. (Zentkteler, 1971, 1972).

Following those initial discoveries, many studies have been conducted to develop haploids in Brassica plants. Using anther or isolated microspore cultures, haploids and DH have been produced in Brassica ssp. Brassica anther culture was successfully used by Keller et al. (1975) and Thomas and Wenzel (1975). Alternatively, in 1982, Lichter developed an isolated microspore culture system for $B$. napus. These techniques have been gradually developed and constantly improved (Cegielska-Taras et al., 2002; Forster and Thomas, 2005; Palmer et al., 2005; Smýkalová et al., 2006; Ferri and Keller, 2007; rev. Pratap et al., 2009; rev. Touraev et al., 2009; Bohownik et al., 2011; Takahira et al., 2011; Murovec and Bohanec, 2012). Protocols for isolated microspore culture of $B$. napus vary among laboratories, especially for cultivating donor plants, harvesting buds, isolating microspores, inducing microspores for division, converting microspore-derived embryos to plantlets, and doubling of chromosome. Protocols for B. napus have been successfully extended to other Brassica species too.

Generally, the yield of androgenic plants in the microspore culture of Brassica species is higher than in the anther culture. In the method of microspore culture, every microspore is potentially capable of regenerating into a viable embryo, and each plant, therefore, represents the genetic variation that exists in the population of microspores. Plant regeneration occurs either by di- rect embryogenesis or by secondary embryogenesis followed by organogenesis. A number of factors influence microspore embryogenesis including genotype, donor plant genotype growth conditions, the stage of explant development, pretreatment composition of the culture medium, and environmental conditions during the culture or the diploidization process. A large part of these factors have to be optimized for each microspore donor genotype (Cegielska-Taras, 2002; Babbar et al., 2004; Gu et al., 2004; Friedt and Zarhloul, 2005; Zhang et al., 2006; Gil-Humanes and Barro 2009; Pratap et al., 2009; Ferrie and Caswell, 2011; Ferrie and Möllers, 2011; Islam and Tuteja, 2012).

The key for increased regeneration efficiency during androgenesis largely depends on the control of two main developmental switches: the induction of microspore cell division and its ultimate commitment to the embryogenic pathway and diploidization rate (Maraschin et al., 2005).

Most plants obtained from the microspore culture of $B$. napus are haploid, which, in turn, must be diploidized. The frequency of spontaneous chromosome doubling is about $10-20 \%$ and varies among genotypes (Weber et al., 2005; Takahira et al., 2011); therefore, artificial chromosome duplication is required. The use of antimitotic substances immediately after the microspore isolation is the most effective method of artificial chromosome duplication (Zhou et al., 2002) and of obtaining microspore-derived embryos (Mohammadi et al., 2012). DH plants are produced by doubling the chromosome number of a haploid plant, while the conventional homozygous inbred lines are developed by selfing in successive generations. With the DH method, homozygous plants produced in one generation show a homozygosity of $100 \%$ compared to the conventional method, which results in an average level of homozygosity of $96.9 \%$, that is, after five to six generations of selfing (Briggs and Knowles, 1967).

One of the principal advantages of haploid techniques is the fixation of segregating genotypes occurring at a lower frequency, in which the recessive gene coding for specific traits is combined in the homozygous condition (Friedt and Zarhloul, 2005).

Microspore culture plays a significant role in both fundamental and practical research. A number of review articles are found on the use of microspore culture and the resulting DH plants (Maluszynski et al., 2003; Forster and Thomas, 2005; Palmer et al., 2005; Friedt and 
Snowdon, 2009; Pratap et al., 2009). This technique is simple and used in the production of $B$. napus $\mathrm{DH}$ plants; this method is highly preferred compared to classical breeding methods. Therefore, microspore culture is the method of choice in plant genetic research and breeding programs.

DHs of $B$. napus, besides being used for the production of homozygous lines, are also used for selecting lines that possess traits determined by recessive genes. DHs were also used for the basic research of physiology and biochemistry, induction and selection of mutants, improvement of plants through genetic transformation, and broadening the genetic diversity in the process of resynthesis of $B$. napus (Babbar et al., 2004; Palmer et al., 2005; Friedt and Snowdon, 2009; Pratap et al., 2009).

Basic researches on DH technology of oilseed rape and attempts to improve their qualitative and quantitative traits are presented based on the main researches conducted worldwide as well as on the results obtained at the Plant Breeding and Acclimatization Institute NRI in Poznań. The results presented here as well as the publications issued by our Institute were based on the data obtained from experiments performed using doubled haploid lines developed by a technology elaborated by Cegielska-Taras et al. (2002).

\section{Development of molecular markers}

Haploids can efficiently be used in basic studies, for example, to identify molecular markers associated with important traits. For the development of molecular markers, segregating populations for the trait of interest are required. Marker-assisted selection (MAS) allows the detection of desired traits in newly developed varieties at early stages of plant development in breeding programs.

Nowadays, new oilseed rape breeding programs that involve modern methods and techniques of biotechnology, plant physiology, molecular genetics and molecular biology have reached an advanced level. It is expected that new varieties will reveal an excellent result in terms of yield, quality characteristics, or disease and stress resistance. Different, sometimes antagonistic, directions of breeding are carried out in parallel and require increasing flexibility from breeders. To maintain competitiveness in this field, it is necessary to react rapidly to the demands of the oilseed market (Matuszczak, 2013).

However, the need for a rapid change stays in opposition to the traditional model of breeding, or the de- velopment of new varieties through the selection of certain genotypes spanning several growing seasons. To make the breeding process more efficient and effective and, as a consequence, to significantly accelerate the development of new varieties, molecular markers are used for the selection (Mohan et al., 1997; rev. Snowdon and Friedt, 2004; Mikołajczyk et al., 2008; rev. Matuszczak, 2013).

Because of their genetic homogeneity, DH lines are extensively used to determine single nucleotide polymorphisms (SNPs) that are specific for agronomically important traits and may be used as molecular markers in breeding programs. Several mapping populations were developed and association studies were performed along with positional cloning and genomic and transcriptomic sequencing experiments using $B$. napus $\mathrm{DH}$ lines to analyze the crucial genes and regulatory sequences for further application in basic and applied research (Snowdon and Friedt, 2004).

$\mathrm{DH}$ lines were developed to detect SNP in low-linolenic (LL) winter oilseed rape genotypes that were obtained by chemical mutagenesis at the Plant Breeding and Acclimatization Institute-NRI Poznan (Spasibionek, 2006). The LL DH line of winter oilseed rape, DH219/05, was selected from a population of $\mathrm{DH}$ lines developed by in vitro culture of isolated microspores from the LL M681 mutant line of $B$. napus (C18:3 $\leq 3 \%$ ) obtained using ethyl methanesulfonate (EMS) (Spasibionek, 2006). Total DNA was isolated from a wild-type line and the LL mutant DH219/05 line and FAD3 desaturase alleles from the homeologous $\mathrm{A}$ and $\mathrm{C}$ genomes of $B$. napus (BnaA.FAD3 and BnaC.FAD3 ). Obtained DNA preparations were polymerase chain reaction (PCR) amplified, cloned, and sequenced (Mikołajczyk et al., 2010a). As a result, two statistically important point mutations were detected: one with a $\mathrm{C}$ to $\mathrm{T}$ transition in the mutant bnaA.fad3 gene leading to a possible Arg to Cys substitution and another with a $\mathrm{G}$ to $\mathrm{A}$ transition in the $5^{\prime}$ donor splice site of the mutant bnaC.fad3 gene, disrupting intron sixth splicing. In addition, the total RNA was isolated from the developing seeds of wild-type and mutant $\mathrm{DH}$ lines eight weeks after pollination. They were used for reverse transcription reaction to confirm the detected SNPs as well as to analyze the splicing variants for bnaA.FAD3 and bnaC.FAD3 (Mikołajczyk et al., 2010a). Functional genetic markers for monitoring FAD3 alleles in breeding programs were developed, and the detection 
of wild-type and mutant $F A D 3$ alleles comprised 1) independent PCR amplification of short fragments comprising SNPs and 2) the detection of SNPs based on the microsequencing method (SNaPshot) using allele-specific primers (Mikołajczyk et al., 2010a).

This unique SNaPshot assay enables a precise and unambiguous detection of the allelic variability in programs accompanied by MAS, including recombinant and hybrid breeding of the LL forms of winter oilseed rape.

\section{DH populations to construct genetic maps}

A DH population is ideal for genetic mapping (Maluszynski, 2003). Genetic mapping is one of the methods by which important crops are studied to identify the molecular markers which are linked to the valuable traits of the plant under study. In particular, when dealing with quantitative traits, influenced by many various genes, the localization of quantitative trait loci on the genetic map becomes a very important step in the genetic studies being performed.

For mapping $B$. napus, DH populations are commonly used, and it seems that their use has been consistently increasing (Lombard and Delourme, 2001; Parkin et al., 2005; Delourme et al., 2006; Kaur et al., 2009). A good illustration of this general tendency is the fact that among all Brassica mapping populations currently listed on the website Brassica.info, 70\% (16) are $\mathrm{DH}$ populations and only $30 \%$ (7) are other types of populations (King and Baten, 2015). The most significant achievement of these studies is the construction of integrated maps of $B$. napus. A good example of such integration is the construction of a genetic map using three distinct DH populations and the subset of RFLP, SSR, RAPD, AFLP and SNP markers. The obtained BnaWAIT_01_2010a integrated linkage map contains 5,162 markers representing 2,196 unique loci (Wang et al., 2011). Other studies focused on the comparison of two maps based on DH (190 lines) and recombinant inbred line (94 lines) populations developed from the same cross (two diverse $B$. napus cultivars "Polo" and "Topas" were crossed). The maps were prepared based on SSR, SRAP, ISSR and SCAR markers. Data from the two genetic maps were used to construct a consensus integrated genetic map covering a total genome length of $2464.9 \mathrm{cM}$ (Geng et al., 2012).

There are at least two reasons for the $\mathrm{DH}$ populations to be preferred during the process of map con- struction. Both reasons arise from the fact that in $\mathrm{DH}$ lines, all the loci exist in homozygous state. First, the $\mathrm{DH}$ population is practically immortal and it can be maintained over many years simply by selfing each line, without any genetic changes in subsequent generations. This makes it a good material for any genetic study or phenotypic analysis in various environments. Second, the $\mathrm{DH}$ population has a very simple pattern of segregation (the theoretical proportion of two alleles is $1: 1$ for each locus), which is of great value if the localization of QTLs for some complex traits is considered. When using dominant markers (e.g., RAPD or AFLP), the use of DH population is the only possible choice because dominant markers are unable to detect loci in the heterozygous state that are present in the $\mathrm{F}_{2}$ population.

Isolated microspore culture method has been successfully used to produce DH plants and to the development of DH population (Matuszczak et al., 2001). A total of $320 \mathrm{DH}$ plants thus obtained were derived from the F1 hybrid obtained from the crossing of parental lines DH-JN-86 (R1) $\times$ DH-ER $-13 / 1(\mathrm{R} 2)$. The seeds of the first parent had a low erucic acid and high glucosinolate content, whereas the seeds of the second parent had a high erucic acid and low glucosinolate content. The DHJN-86 line was derived from the Jet Neuf variety, and the $\mathrm{DH}_{-}-\mathrm{ER}_{2}-13 / 1$ line was from our own breeding materials. The subset of $117 \mathrm{DH}$ lines served as a basis for the construction of genetic map. This mapping population, as well as parental lines, were studied using RAPD (Matuszczak and Krzymański, 1999) and AFLP (Matuszczak, 2002) markers. Today, the obtained genetic map continues to consist of 75 markers grouped in 19 linkage groups. Since the parental forms exhibit variations in important agronomic traits such as erucic acid and glucosinolate contents in seeds, our research focused on the finding of QTLs for these traits. Fifty-eight various QTLs have been localized on the map so far (Matuszczak, 2010; Matuszczak et al., 2011).

The study on the yellow-seeded oilseed rape with improved seed meal quality is another example. This trait in $B$. napus is generally associated with a reduced seed coat thickness and consequent lowering of antinutritive crude fiber and phenolic compounds (Friedt and Snowdon, 2009). Yellow seeds do not occur naturally among the genotypes of $B$. napus. In various research groups, there are many forms of yellow oilseed rape lines obtained by transferring this trait from other yellow- 
seeded Brassica species or obtained as mutations (Cegielska-Taras, 2002; rev. Rahman and McVetty, 2011). In genetic mapping, these yellow-seeded materials are used to identify the major genes that contribute to reduced seed coat and to develop markers related to this trait (Friedt and Snowdon, 2009). The Polish source of yellow-seeded $B$. napus was derived from the crosses of a spontaneous mutant with lighter seeds, found in the breeding material of a double low winter rapeseed, with segregating, spotted-seed-coat spring line, from earlier crosses of Brassica napus $\times$ Brassica rapa var. oleifera. The lines thus obtained were further improved with respect to quality traits and then those that showed a stable expression for yellow seediness were selected (Bartkowiak-Broda et al., 2011). Using androgenesis in vitro of isolated microspores of bright color lines, yellow-seeded $\mathrm{DH}$ lines were developed. Two yellow-seeded lines DH Z129 and DH Z114 were used for reciprocal crosses with black-seeded DH lines DH H5-105 and DH W40. Hence, for creating genetic maps of $B$. napus, two segregating populations consisting of $200 \mathrm{DH}$ lines were used. All DH lines were analyzed using RAPD, AFLP, and SSR methods. As a result of the research, 889 polymorphic amplification products were obtained, but for the construction of a genetic map, only 349 of potential genetic markers could be used. Field experiments with these $\mathrm{DH}$ lines in two environments were carried out for four years to obtain the data of their phenotypic characteristics. These data will be used to create a genetic map of the yellow-seeded oilseed rape.

\section{Mutagenesis and selection in vitro}

A mutation technique was applied to improve the yield and quality of the crop and to develop resistance to diseases and pests. Many novel genotypes with desired traits have been obtained (Szarejko, 2003). In B. napus, microspores and haploid tissues have been used as a material for mutation (Kott et al. 1996; Cegielska-Taras and Szała, 2001; Szarejko, 2003; Li et al., 2005). A mutagenic treatment of a single, potentially totipotent haploid cell (e.g., an isolated microspore), followed by rapid differentiation in the embryo, represents a unique opportunity for screening homozygotic, non-chimerical M1 organisms for resistance to particular agents. Thus, the mutant production cycle can be shortened significantly. Haploid cells (microspores) or haploid tissue and selection can yield a plant population with genetically fixed novel traits. The advantage of using a large-scale microspore selection system over a traditional somatic tissue selection system is evident (Cegielska-Taras and Szala, 2001). Mutation methods combined with in vitro selection, especially at the haploid level, to select genotypes with traits controlled by either recessive or dominant genes, improves the collection of desired mutants. In $B$. napus, haploid cells and tissues have been used to select mutants for herbicide resistance, disease resistance, lower glucosinolate content, fatty acid composition, long pods and short stems, and DH lines with improved resistance to Sclerotinia sclerotiorum and better agronomic characters (rev. Li et al., 2005).

The methods of early in vitro selection of microspore-derived embryo (MDE) genotypes discussed here appear to be promising for further optimization of $\mathrm{DH}$ technology in oilseed rape (Ferrie and Möllers, 2011). The number of PCR-based DNA markers for agronomically important traits is increasing and will allow for a more efficient MAS in segregating MDE populations at an early in vitro developmental stage (Ferrie and Möllers, 2011).

One such example is the application of DH techniques with a method of early selection for erucic acid in cotyledons of MDEs. In this study, the seeds of the selected DH lines had higher erucic acid, that is, more than 50\%. The erucic acid contents (expressed in percent of the total fatty acid content) of the cotyledons of embryos and of the seeds derived from plant regenerated from the remaining parts of the embryos were highly correlated. Results showed that the selected DH lines had high erucic acid content along with high oil content (Cegielska-Taras et al., 1999).

\section{Genetic modification of $B$. napus}

Oilseed rape ( $B$. napus L.) is particularly susceptible to Agrobacterium tumefaciens-mediated transformation allowing a considerable progress in the development of genetically modified varieties (Friedt and Snowdon, 2009).

The limitations of initial regeneration systems and problems with combining regeneration and transformation within the same cells are the major constraints hindering the advancement of plant transgenesis. The essential elements of successful plant transgenesis include the choice of cells and organs for recipients of the introduced gene and an efficient system for the selection of cells containing an integrated foreign gene in the ge- 
nome. In order for the genes to be successfully transferred, the cells and tissues have to represent a high regenerative capacity to develop into a complete and normal transgenic organism. DHs obtained by tissue cultures of microspores and MDEs show uniformity, and as a complete homozygous, they can also be efficiently used in genetic transformation (Fukuoka et al., 1998; Nehlin et al., 2000; Takahata et al., 2005; Cegielska-Taras et al., 2008). The gene introduced into a haploid genome, which in this case was an MDE and subsequent chromosome doubling, gives rise to a homozygous transgenic oilseed rape (Cegielska-Taras et al., 2008b; Cegielska-Taras and Pniewski, 2011).

One of the first successful attempts to obtain a transgenic herbicide-resistant winter oilseed rape was the transformation of haploid MDEs using hypervirulent A. tumefaciens' EHA105 strain (Cegielska et al., 2008b). In this way, two biotechnological methods of oilseed rape - DH and genetic modification - were combined.

The elaborated MDE transformation method of winter oilseed rape allows to obtain genetically modified plants (Cegielska-Taras et al., 2008b; Cegielska-Taras and Pniewski, 2011). The main advantage of this method is that as a result of chromosome duplication in the transformed haploid, the introduced trait can be evaluated in a single step, as a transgenic homozygote. The production of transgenic homozygous oilseed rape provides a unique material for further studies of the inheritance and functionality of genes introduced through a subsequent generation, that is, for basic research, breeding programs, and utilitarian purposes. An alternative path to obtain oilseed rape with new quality traits is by transferring particular foreign genes to a plant genome.

Many projects have aimed at obtaining transgenic $\mathrm{DH}$ lines; one such example is an attempt to obtain DHs that are tolerant to drought stress. The genetic source that expresses resistance to drought in $B$. napus is unknown. Hence, there is a need to explore the mechanisms that increase the tolerance toward drought stress and also genetic manipulations and to widen the range of genetic variability of this species. It is expected that studies that focus on the above points will result in $\mathrm{DH}$ lines that are tolerant to water deficiencies.

Drought stress induces diverse changes at the cellular and molecular level and is associated with the production of plant phytohormones, especially abscisic acid (ABA). The key role in the regulation of ABA signaling is attributed to protein phosphatases such as ABI1 and ABI2 (ABA insensitive). Protein phosphatases, which are negative regulators of $\mathrm{ABA}$ signaling, interact with various targets to form a regulatory core modulating cellular processes and stress response pathways. Moreover, the concentration of calcium $\left(\mathrm{Ca}^{2+}\right)$ in the cytoplasm increases substantially in response to some factors of stress. The information about stress (an increase in the calcium concentration) is sensed by numerous proteins, including Ca-dependent protein kinases (CDPKs). In the study described here, the coding regions of the Arabidopsis thaliana AtABI1 and AtCDPK6 genes were inserted into the vector pPKGIB, and these constructs were introduced into B. napus via MDEs with Agrobacterium mediated transformation (Babula-Skowrońska et al., 2015; Olejnik et al., 2011). Three independent AtABI1overexpressing $B$. napus $\mathrm{DH}$ lines such as 41,42 , and 45 were investigated with respect to their drought stress response. The authors found that the overexpression of AtABI1 in B. napus negatively influences several important cellular processes such as relative water content (RWC), chlorophyll accumulation, and the expression profile of several ABA- and/or dehydration stress-inducible genes. These data show that the function of ABI1 protein phosphatase is highly conserved within the Brassicaceae family. Furthermore, it functions as a regulatory hub protein for dehydration stress responses in plants. Interestingly, there are six $A B I 1$-related genes in the $B$. napus genome, which are formed by polyploidization during evolution. To investigate the functional diversification of the duplicated $B$ naABI1 gene copies, two evolutionarily distant $B n a A B I 1$ genes such as BnaA01.ABI1. $a$ and BnaC07.ABI1.b were selected. The expression pattern of these genes showed differences indicating the differential involvement of the duplicated $B n a A B I 1$ genes in the response of $B$. napus to drought. These results shed new light on the diverse role of the $A B I 1$ gene family in the drought response plasticity in the Brassica polyploid (Babula-Skowrońska et al., 2015).

\section{Resynthesis of $B$. napus}

The level of genetic diversity in double-low genotypes is relatively low. It is caused above all by intensive selection of genotypes in terms of two features associated: with improving oil, through eliminating erucic acid and with improving the meal, through the reduction of glucosinolates content. Today, oilseed rape breeders are 
seeking genetic diversity in their breeding programs. A particularly successful method used to create a novel genetic variety is wide hybridization in a special resynthesis of $B$. napus from ancestral species $B$. oleracea and $B$. rapa. The resynthesized (RS) oilseed rape (B. napus) is potentially of great interest for hybrid varieties breeding because its heterosis effects are reported to be higher in crosses of genetically distant materials. A major problem using RS lines of $B$. napus in hybrid varieties breeding is the quality of their seed oil (high level of erucic acid) and seed meal (high glucosinolates content), which does not comply with the double-low quality of oilseed rape. Additional treatments are needed for breeding before introducing RS B. napus in practice. Szała et al. (2015a) described RS oilseed rape obtained through crosses between $B$. rapa ssp. chinensis var. chinensis (pak choy) and B. oleracea ssp. acephala var. sabellica (curly kale) using embryo rescue technique. Several RS oilseed rape lines obtained by this technique were crossed with double-low winter oilseed rape possessing Rfo gene for CMS ogura hybridization system. Large numbers of androgenic plant populations (semi-RS DH lines) were developed from $\mathrm{F} 1$ hybrids using a microspore in vitro culture method. The seeds of the obtained semi-RS DH lines were analyzed biochemically with regard to doublelow quality (zero erucic acid and glucosinolates content). From the populations of the semi-RS DH, genotypes with double-low quality and $R f o$ gene were selected. Currently, the obtained semi-RS DH lines with Rfo gene and doublelow quality are being used to produce new components of winter oilseed rape for the development of CMS ogura hybrids (Szała et al., 2015a).

\section{Improvement of the quality of oilseed rape oil}

At present, much attention is paid to the nutritional value of oilseed rape oil obtained from double-low cultivars.

With regard to nutrition, oilseed rape is a very valuable oil product, and it is not only a source of essential unsaturated fatty acids but also a source of natural antioxidants with other endogenous bioactive substances in seeds such as tocochromanols, sterols, beta-carotene, and phenolic compounds. The quality of $B$. napus oil is also enhanced by the presence of a series of beneficial hydrophobic compounds including carotenoids, tocochromanols, and phytosterols (Cegielska-Taras et al., 2008a, 2011). Carotenoids and tocochromanols are important antioxidants and essential components of human diet providing a source of provitamin A (beta-carotene) and vitamin $\mathrm{E}$ (alpha-tocopherol).

A three-year study was performed on the range of the genetic variation among DHs to determine the effect of the genotype and the environment on tocopherol (T) and plastochromanol-8 (PC-8) content in winter oilseed rape (B. napus L.). The plant material consisted of 25 $\mathrm{DH}$ lines derived from the $\mathrm{F} 1$ hybrid obtained from the cross between two DH lines $(Z \times H)$, (Z-114 - yellow seeds; $\mathrm{H}_{2}-26$ - black seeds) (Sieger et al., 2015). Among all the genotypes analyzed, 11 were selected as satisfactory and stable regarding tocopherol or PC-8 contents. From the breeding point of view, high heritability of traits guarantees the effectiveness of the selection and a rapid biological progress. The results of this study confirm the desirability of making changes to tocopherol and PC- 8 contents using DH line technology. The lines obtained of the $\mathrm{DH}$ population derived from $\mathrm{F} 1$ plants of the cross between yellow and black seeds are characterized by different color of seeds, which correlated with their tocopherol homologues content. The high coefficients of heritability for $\alpha-\mathrm{T}, \gamma-\mathrm{T}$, and PC- 8 suggest a possibility of an effective selection based on the phenotype, allowing to obtain DH lines with a stable expression of traits. This suggests that $\alpha-\mathrm{T}, \gamma-\mathrm{T}$, and PC- 8 contents depend more on the genotype than on the environmental influence. This dependence is confirmed by a statistical analysis (Siger et al., 2015).

Phytosterols are produced by isoprenoid biosynthetic pathway and possess the properties of lowering LDL cholesterol. Thus, it would be highly desired to select high phytosterol content in oilseed rape oil (Amar et al., 2008). Recently, three QTLs for total phytosterol content were detected in a winter oilseed rape DH population, explaining $60 \%$ of the genetic variance for this trait.

The study on $44 \mathrm{DH}$ lines of winter oilseed rape showed a large and significant variation of its total phytosterol and fat contents. The large genotypic differences in total phytosterol content indicate that an effective selection of genotypes with higher phytosterol content, in a cultivar development program, would be possible (Cegielska-Taras et al., 2011).

\section{Hybrid breeding of winter oilseed rape}

Currently, the breeding programs of rapeseed worldwide as well as in Poland are focused consistently on the 
development of hybrid varieties which display an improved yield performance and better stability owing to the heterosis effect. The benefit of heterosis depends on the specific combining ability and genetic distance of parental lines which should be homozygous. Most breeding programs are based on cytoplasmic male sterility (CMS) systems, controlling cross pollination, while homozygous restorer lines are necessary to exploit heterosis effect. Today, DHs are widely used for producing homozygous parental restorer lines for breeding oilseed rape hybrids (Poplawska et al., 2007; Friedt and Snowdon, 2009).

In the CMS ogura system used in Poland as well as in many other breeding centers in the world, the restoration of fertility is achieved by a single restorer gene $R f o$. The restorer has to be incorporated into a gene pool distant from the gene pool of male sterile lines. DH lines can be produced right away from F1 plants or starting from later selfing generations, which allows for some early testing (Frauen, 1994; Möllers and Iqbal, 2009; Paulmann and Frauen, 1997; Popławska et al., 2006).

DH lines possessing the Rfo restorer gene were selected after molecular analyses using specific biochemical and genetic markers. The biochemical assay used to detect the Raphanus sativus Pgi-2 isozyme locus closely linked to the Rfo gene (Delourme and Eber, 1992) was applied (Poplawska et al., 2007) in addition to other molecular markers. At the beginning, the OPC02 RAPD marker (Delourme et al., 1994) was used for monitoring the $R f o$ gene in parallel to the specific SCAR marker for the CMS ogura (Sigareva and Earle, 1997). Then, the Rfo RAPD marker was converted to an SCAR one (Mikołajczyk et al., 2008), which was further combined with the "CMS" SCAR marker for developing a multiplex PCR assay (Mikołajczyk et al., 2010b), making the selection of $\mathrm{DH}$ lines with the Rfo restorer gene more time-, labor-, and cost-effective.

\section{DH technology in winter oilseed rape breeding programs}

Generally, because of the high response of $B$. napus genotypes to microspore culture techniques, the use of $\mathrm{DH}$ production has become a common practice in commercial breeding programs and has already resulted in numerous licensed varieties.

The most important benefits of using haploid plants in the breeding of new varieties are as follows: 1 ) homozygous recombinant line can be developed in one genera- tion instead of numerous backcross generations; 2) selection for recessive traits in recombinant lines is more efficient since these are not masked by the effects of dominant alleles; and 3) varieties can be developed in reduced time period, for example, at least from 12 to 8 years.

Microspore culture is a useful tool in plant breeding because homozygous lines exhibiting the desired agronomic traits can be rapidly selected, which creates an opportunity for faster production of commercial cultivars. A breeding program of Canadian spring canola cultivar Quantum lasted five years (Stringam et al., 1995). It resulted in the selection of DH line which is characterized by a high yield and agronomically superior blackleg resistance. The other winter oilseed rape DH line, cultivar Mohican, was developed in the UK (Kučera et al., 2002). Currently, most of the Canadian spring oilseed rape cultivars that are grown are derived using DH technology (Ferrie and Möllers, 2011).

An open-pollinated cultivar Monolit (Plant Breeding Strzelce Ltd., Co.) is the first Polish winter oilseed rape variety obtained using DH technology (Cichy et al., 2005). The breeding cycle of this variety was about four years shorter than a classical breeding program. The second Polish winter oilseed rape variety being the $\mathrm{DH}$ line was registered as cv. Brendy (Plant Breeding Smolice Ltd., Co.). It is a DH line which was licensed in 2013. Both cultivars were obtained from isolated microspore culture in vitro at the Plant Breeding and Acclimatization Institute NRI in Poznań.

Numerous DH populations of winter oilseed rape obtained from an isolated microspore culture (CegielskaTaras et al., 2002) have been widely used in various statistical researches, for example, to study the influence of environmental conditions on the stability of important yield components and the transgression effects of advantageous traits (Szała et al., 2015b).

\section{Conclusions}

Androgenesis in vitro is one of the most widely used culture techniques which has miscellaneous applications. The production of $\mathrm{DH}$ plants through a microspore culture is the milestone in the development of research on the genome of rapeseed at different levels and using different technologies. It is also used to determine the effectiveness of breeding programs.

It seems that the positive results of molecular studies on the identification of genes responsible for trigge- 
ring the induction of divisions of isolated microspores of B. napus in in vitro culture may become another step in the improvement of DH technology.

\section{Acknowledgment}

This work was partially supported by the Ministry of Agriculture and Rural Development, Poland Project HORhn No. 52, 2014-2016.

\section{References}

Amar S., Ecker W., Becker H.C., Möllers C. (2008) QTL for phytosterol and sinapate ester content in Brassica napus L. collocate with the two erucic acid genes. Theor. Appl. Genet. 116: 1051-1061.

Babbar S.B., Agarwal P.K., Sahay S., Bhojwani S.B. (2004) Isolated microspore culture of Brassica: An experimental tool for developmental studies and crop improvement. Indian J. Biotech. 3: 185-202.

Babula-Skowrońska D.; Ludwików A., Cieśla A., Olejnik A., Cegielska-Taras T., Bartkowiak-Broda I., Sadowski J. (2015) Involvement of genes encoding ABI1 protein phosphatases in the response of Brassica napus $L$. to drought stress. Plant Mol. Biol. 88: 445-457.

Bartkowiak-Broda I., Piotrowska A., Hernacki B., Michalski K., Krotka K. (2011) Genetic and molecular analysis of specific-origin yellow-seeded winter rapeseed (B. napus $L$. var. oleifera). Proceedings of $13^{\text {th }}$ International Rapeseed Congress, June 05-09, 2011, Prague. www.irc2011.org.

Blakeslee J., Belling M.E., Farnham M.E., Bergner A.D. (1922) A haploid mutant in the Jimson weed, Datura stramonium L. Science 55: 646-647.

Bohowmik P., Dirpaul J., Polowick P., Ferrie A. (2011) A high throughput Brassica napus microspore culture system: influence of percoll gradient separation and bud selection on embryogenesis. Plant Cell Tiss. Organ. Cult. 1066: 359-362.

Briggs F.N., Knowles P.F. (1967) Introduction to Plant Breeding. New York Reinhold Pub. Corp.

Cegielska-Taras T. (2002) The use of microspores cultures for genetic improvement of winter oilseed rape (Brassica napus). Monografie i Rozprawy Naukowe IHAR 18: 7-107 (in Polish).

Cegielska-Taras T., Nogala-Kałucka M., Bartkowiak-Broda I., Siger A., Szała L. (2008a) Tocochromanols and fat content in seeds of winter oilseed rape (Brassica napus L.) doubled haploids. In: Advance in Analysis and Technology of Rapeseed Oil, Monograph I. Ed. Szłyk E. Toruń: Wyd. Nauk. UMK: 23-33.

Cegielska-Taras T., Nogala-Kałucka M., Rudzińska M., Szała L., Siger A., Kaczmarek Z., Adamska E. (2011) Study of the comparing of sterols and fat content in populations of doubled haploids of winter oilseed rape (Brassica napus L.). In: Advances in Research and Technology of Rapeseed Oil, Monograph III. Ed. Szłyk E. Toruń: Wyd. Nauk. UMK: 21-32.
Cegielska-Taras T., Pniewski T. (2011) The use of herbicides in biotech oilseed rape cultivation and in generation of transgenic homozygous plants of winter oilseed rape (Brassica napus L.). In: Herbicide - Mechanisms and Mode of Action. Ed. Hasaneen M.N.A. InTech 7: 125-137.

Cegielska-Taras T., Pniewski T., Szała L. (2008b) Transformation of microspore-derived embryos of winter oilseed rape (Brassica napus L.) by using Agrobacterium tumefaciens. J. Appl. Gen. 49: 343-347.

Cegielska-Taras T., Szała L. (2001) Induced mutation for the generation of herbicide-resistant doubled haploids of Brassica napus L. Biol. Bull. Poznań 38: 43-47.

Cegielska-Taras T., Szała L., Nałęczyńska A., Kołodziej K., Ogrodowczyk M. (1999) In vitro selection for high erucic acid content in microspore-derived embryos of winter oilseed rape (Brassica napus L.). J. Appl. Genet. 40: 305-315.

Cegielska-Taras T., Tykarska T., Szała L., Kuraś L., Krzymański J. (2002) Direct plant development from microsporederived embryos of winter oilseed rape Brassica napus $L$. ssp. oleifera (DC.). Metzger. Euphytica 124: 341-347.

Cichy H., Budzianowski G., Cegielska-Taras T., Szała L. (2005) Winter oilseed rape cultivar developed by the use of doubled haploids. Rośl. Oleiste - Oilseed Crops. XXVI: 589593 (in Polish).

Delourme R.,.Bouchereau A., Hubert N., Renard M., Landry B.S. (1994) Identification of RAPD markers linked to a fertility restorer gene for the Ogura radish cytoplasmic male sterility of rapeseed (Brassica napus L.). Theor. Appl. Genet. 88: 741-748.

Delourme R. Eber F. (1992) Linkage between an isozyme marker and a restorer gene in radish cytoplasmic male sterility of rapeseed (Brassica napus L.). Theor. Appl. Genet. 85: 222-228.

Delourme R., Falentin C., Huteau V., Clouet V., Horvais R., Gandon B., Specel S., Hanneton L., Dheu J.E., Deschamps M., et al. (2006) Genetic control of oil content in oilseed rape (Brassica napus L.). Theor. Appl. Genet. 113: 1331-1345.

Ferrie A.M.R., Caswell K.L. (2011) Isolated microspore culture technique and recent progress for haploid and doubled haploid plant production. Plant Cell Tiss. Organ. Cult. 104: 301-309.

Ferrie A.M.R., Keller W.A. (2007) Optimization of methods for using polyethylene glycol as a non-permeating osmoticum for the induction of microspore embryogenesis in the Brassicaeae. In Vitro Cell. Dev. Biol. 43: 348-355

Ferrie A.M.R., Möllers C. (2011) Haploid and doubled haploids in Brassica spp. for genetic and genomic research. Plant Cell Tiss. Organ. Cult. 104: 375-386.

Forster B.P., Thomas W.T.B. (2005) Doubled haploids in genetics and plant breeding. Plant Breed Rev. 25: 57-88.

Frauen M. (1994) Use of biotechnology in breeding new varieties of winter oilseed rape in Germany. Bul. GCIRC 10: 16-29.

Fried W., Snowdon R. (2009) Oilseed rape. In: Oil crops. Ed. Vollmann J., Rajcan I. Dordrecht, Heidelberg, London, New York, Springer 4: 91-126. 
Friedt W., Zarhloul M.K. (2005) Haploids in the Improved of Crucifers. In: Biotechnology in Agriculture and Foresty. Ed. Palmer C.E., Keller W.A., Kasha K.J. Berlin, Heidelberg: Springer-Verlag 56: 191-213.

Fukuoka H., Ogawa T., Matsuoka M., Ohkawa Y., Yano H. (1998) Direct gene delivery into isolated microspores of rapeseed (Brassica napus L.) and the production of fertile transgenic plants. Plant Cell Rep. 17: 323-328.

Geng J., Javed N., McVetty P.B.E., Li G., Tahir M. (2012) An integrated genetic map for Brassica napus derived from double haploid and recombinant inbred populations. Hered. Genet. 1: 103. doi: 10.4172/2161-1041.1000103.

Gil-Humanes J., Barro F. (2009) Production of doubled haploids in Brassica. In: Advances in Haploid Production in Higher Plants. Ed. Touraev A. et al. Springer Science + Business Media B.V. 4: 65-73.

Gu H.H., Hagberg P., Zhou W.J. (2004) Cold pretreatment enhances microspore embryogenesis in oilseed rape (Brassica napus L.). Plant Growth Regul. 42: 137-143.

Guha S., Maheshwari S.C. (1964) In vitro production of embryos from anthers of Datura. Nature 204: 497.

Guha S., Maheshwari S.C. (1966) Cell division and differentiation of embryos in the pollen grains of Datura in vitro. Nature 212: 97-98.

Islam S.M.S., Tuteja N. (2012) Enhancement of androgenesis by abiotic stress and other pretreatments in major crop species. Plant Sci. 182: 134-144.

Kaur S., Cogan N.O.I., Ye G., Baillie R.C., Hand M.L., Ling A.E., Mcgearey A.K., Kaur J., Hopkins C.J., Todorovic M., et al. (2009) Genetic map construction and QTL mapping of resistance to blackleg (Leptosphaeria maculans) disease in Australian canola (Brassica napus L.) cultivars. Theor. Appl. Genet. 120: 71-83.

Keller W.A., Rajhathy R. Lacapra J. (1975) In vitro production of plants from pollen in Brassica campestris. Can. J. Genet. Cytol. 17: 655-666.

King G.J., Baten A. (2015) Genetic maps. Published map data. http://www.brassica.info/resource/maps/publisheddata.php. Accessed 23 April 2015.

Kott L., Wong R., Swanson E., Chen J. (1996) Mutation and selection for improved oil and meal quality in Brassica napus utilizing microspores culture. In: In vitro haploid production in higher plants, vol 2. Eds. Jain S.M., Sopory S.K., Veilleux R.E. Springer: Berlin-Heidelberg-New York: 151-167.

Kučera V., Vyvadilová M., Klíma M. (2002) Utilization of doubled haploids in winter oilseed rape (Brassica napus L.). Czech J. Genet. Plant Breed. 38: 50-54.

Li S., Wang H., Zhang J., Fitt B.D., Xu Z., Evans N., Liu Y., Yang W., Guo X. (2005) In vitro mutation and selection of doubled-haploid Brassica napus lines with improved resistance to Sclerotinia sclerotiorum. Plant Cell Rep. 24: 133-144.

Lichter R. (1982) Induction of haploid plants from isolated pollen of Brassica napus. Z. Pflanzenphysiol. 103: 229237.
Lombard V., Delourme R. (2001) A consensus linkage map for rapeseed (Brassica napus L.): construction and integration of tree individual maps from $\mathrm{DH}$ populations. Theor. Appl. Genet. 103: 491-507.

Maluszynski (2003) Doubled haploid production in crop plants: a manual. Dordrecht: Kluwer.

Maluszynski M., Kasha K.J., Szarejko I. (2003) Published doubled haploid protocols in plant species. In: Doubled Haploid Production in Crop Plants. Ed. Manual A., Maluszynski M., Kasha K.J., Forster B.P., Szarejko I. Dordrecht: Kluwer Academic Publishers: 309-335.

Maraschin S.F., de Priester W., Spaink H.P., Wang M. (2005) Androgenic switch: an example of plant embryogenesis from the male gametophyte perspective. J. Exp. Bot. 56: 1711-1726.

Matuszczak M. (2002) Zastosowanie metody AFLP do analizy DNA rzepaku ozimego. Rośliny Oleiste - Oilseed Crops XXIII: 255-265 (in Polish).

Matuszczak M., Cegielska-Taras T., Szała L., Krzymański J. (2001) Populacja linii podwojonych haploidów rzepaku ozimego - etapy otrzymywania oraz wstępna charakterystyka za pomocą markerów RAPD. XIV Zjazd Polskiego Towarzystwa Genetycznego: Genetyka w służbie człowieka, 1113. 06. 2001, Poznań, Poland, Streszczenia: 252 (in Polish).

Matuszczak M. (2013) Molecular markers for study of oilseed rape (Brassica napus L.) II. The review of markers used for breeding programs. Rośliny Oleiste - Oilseed Crops XXXIV: 151-166 (in Polish).

Matuszczak M., Krzymański J. (1999) Poszukiwanie markerów $R A P D$ różnicujących linie rzepaku ozimego o różnych cechach chemicznych. Rośliny Oleiste - Oilseed Crops XX: 395-414 (in Polish).

Matuszczak M., Tokarczuk I., Szała L., Cegielska-Taras T., Krzymański J., Bartkowiak-Broda I. (2011) The localization of many QTLs on the genetic map of winter oilseed rape (Brassica napus $L$. var. oleifera). $13^{\text {th }}$ International Rapeseed Congress, Prague, Czech Republic. Abstarct Book: 1026-1029.

Matuszczak M. (2010) Identyfikacja loci cech jakościowych rzepaku ozimego (Brassica napus L. var. oleifera). Praca doktorska, Instytut Hodowli i Aklimatyzacji Roślin - Państwowy Instytut Badawczy, Zakład Genetyki i Hodowli Roślin Oleistych, Poznań.

Mikołajczyk K., Dabert M., Nowakowska J., Podkowiński J., Popławska W., Bartkowiak-Broda I. (2008) Conversion of the RAPD OPC021150 marker of the Rfo restorer gene into a SCAR marker for rapid selection of oilseed rape. Plant Breed. 127: 647-649.

Mikołajczyk K., Dabert M., Karłowski W., Spasibionek S., Nowakowska J., Cegielska-Taras T., Bartkowiak-Broda I. (2010a) Allele-specific SNP markers for the New low linolenic $\mathrm{mu}$ tant of winter oilseed rape. Plant Breed. 129: 502-507.

Mikołajczyk K., Dobrzycka A., Podkowiński J., Popławska W., Spasibionek S., Bartkowiak-Broda I. (2010b) A multiplex PCR assay for identification of the ogura male sterile cytoplasm and the Rfo restorer gene among oilseed rape bre- 
eding forms. Rośliny Oleiste - Oilseed Crops XXXI: 201 210.

Mohan M., Nair S., Bhagwat A., Krishna T.G., Yano M., Bhatia C.R., Sasaki T. (1997) Genome mapping, molecular markers and marker assisted selection in crop plants. Molec. Breed. 3: 87-103.

Mohammadi P.P., Moieni A., Ebrahimi A., Javidfar F. (2012) Doubled haploid plants following colchicine treatment of microspore-derived embryos of oilseed rape (Brassica napus L.). Plant Cell Tiss. Organ. Cult. 108: 251-256.

Möllers C., Iqbal M.C.M. (2009) Doubled haploids in breeding winter oilseed rape. In: Advances in haploid production in higher plants. Ed. Touraev A., Forster B.P., Jain S.M. Heidelberg: Springer 13: 161-170.

Murovec J., Bohanec B. (2012) Haploids and Doubled Haploids in Plant Breeding. In: Plant Breeding. Ed. Abdurakhmonov I.Y. Croatia: InTech: 5: 87-106.

Nehlin L., Möller C., Bergman P., Glimelius K. (2000) Transient $\beta$ - gus and gfp gene expression and viability analysis of micro-projectile bombarded microspores of Brassica napus L. J. Plant Physiol. 156: 175-183.

Olejnik A., Ludwikow A., Misztal L., Rodakowska E., Cegielska-Taras T., Sadowski J., Bartkowiak-Broda I. (2011) Molecular analysis of $\mathrm{DH}$ lines of winter oilseed rape transformed with genes changing in response to drought stress. $13^{\text {th }}$ International Rapeseed Congress, Prague, Czech Republic. Abstarct Book: 324.

Palmer C. E. Keller W.A., Kasha K.J. (2005) Haploids in crop improvement II. In: Biotechnology in Agriculture and Forestry 56. Ed. Nagata T., Lörz H., Widholm J.M. Berlin, Heidelberg, New York: Springer-Verlag.

Parkin I.A.P., Gulden S.M., Sharpe A.G., Lukens L., Trick M., Osborn T.C., Lydiate D.J. (2005) Segmental structure of the Brassica napus genome based on comparative analysis with Arabidopsis thaliana. Genetics 171: 765-781.

Paulmann W., Frauen M. (1997) The firstly restorer F1-hybrids of winter oilseed rape. GCIRC Bull. 13: 24-25.

Poplawska W., Bartkowiak-Broda I., Szała L. (2007) Genetic and breeding evaluation of doubled haploid lines with restorer gene for CMS ogura system of winter oilseed rape (Brassica napus L.). Brassica 9: 29-32.

Popławska W., Szała L., Cegielska-Taras T., BartkowiwakBroda I. (2006) Genetic and breeding evaluation of doubled haploids lines with restorer gene for CMS ogura system of winter oilseed rape (Brassica napus L.). In: Haploidy $i$ linie podwojonych haploidów w genetyce $i$ hodowli roślin. Ed. Adamski T., Surma M. Instytut Genetyki Roślin PAN w Poznaniu: 151-157 (in Polish).

Pratap A., Gupta S.K., Takahata Y. (2009) Microsporogenesis and haploidy breeding. In: Biology and Breeding Crucifers. Ed. Gupta S.K. London: CRS Press Taylor \& Francis group: 293-307.

Rahman M., McVetty P.B.E. (2011) A review of Brassica seed color. Can. J. Plant Sci. 91: 437-446.

Sigareva M.A., Earle E.D. (1997) Direct transfer of a cold-tolerant Ogura male-sterile cytoplasm into cabbage (Bras- sica oleracea ssp. capitata) via protoplast fusion. Theor. Appl. Genet. 94: 231-220.

Siger A., Michalak M., Cegielska-Taras T., Szała L., Lembicz J., Nogala-Kałucka M. (2015) Genotype and environment effects on tocopherol and plastochromanol-8 contents of winter oilseed rape doubled haploid lines derived from $F 1$ plants of the cross between yellow and black seeds. Industr. Crops Prod. 65: 134-141.

Smýkalová M., Větrovcová M., Klima M., Macháčková I., Griga M. (2006) Efficiency of Microspore Culture for Doubled Haploid production in the Breeding Project "Czech Winter Rape”. Czech J. Genet. Plant Breed. 42: 58-71.

Snowdon R.J., Friedt W. 2004. Molecular markers in Brassica oilseed breeding: current status and future possibilities. Plant Breed. 123: 1-8.

Spasibionek S. (2006) New mutant of winter oilseed rape (Brassica napus L.) with changed fatty composition. Plant Breed. 125: 259-267.

Stringam G.R., Bansal V.K., Thiagarajah M.R., Tewari J.P. (1995) Development of agronomically superior blackleg resistant canola cultivar in Brassica napus L., using doubled haploid. Can. J. Plant. Sci. 81: 107-108.

Szała L., Sosnowska K., Popławska W., Liersch A., Olejnik A., Kozłowska K., Bocianowski J., Cegielska-Taras T. (2015a) Introgression of resynthesized Brassica napus L. into parental lines of winter oilseed rape $F_{1}$ hybrids (in press).

Szała L., Kaczmarek Z., Adamska E., Cegielska-Taras T. (2015b) The assessment of winter oilseed rape DH lines using uniand multivariate methods of quantitative genetics and mathematical methods. BioTechnologia, in the issue.

Szarejko I. (2003) Doubled haploid mutant production. In: Doubled haploid Production in Crop Plants. Ed. M. Maluszynski, Kasha K.J., Forster B.P., Szarejko I. Dordrecht, Boston, London: Kluwer Academic Publishers: 351-361.

Takahata Y., Fukuoka H., Wakui K. (2005) Utilization of microspore-derived embryos. In: Haploids in Crop Improvement II. Ed. Plamer C.E., Keller W.A., Kasha K.J. Berlin, Heidelberg: Springer-Verlag: 153-169.

Takahira J., Cousin A., Nelson M.N., Cowling W.A. (2011) Improvement in efficiency of microspore culture to produce doubled haploid canola (Brassica napus L.) by flow cytometry. Plant Cell Tiss. Cult. 104: 51-59.

Thomas E., Wenzel G. (1975) Embryogenesis from microspores of Brassica napus. Z. Pflanzenzucht. 74: 77-81.

Touraev A., Forster B. P., Jain S.M. (2009) Advances in Haploid Production in Higher Plants. Springer Science + Business Media B.

Wang J., Lydiate D.J., Parkin I.A.P., Falentin C., Delourme R., Carion P.W.C., King G.J. (2011) Integration of linkage maps for the amphidiploid Brassica napus and comparative mapping with Arabidopsis and Brassica rapa. BMC Genomics 12: 101.

Weber S., Ünker F., Friedt W. (2005) Improved doubled haploid production protocol for Brassica napus using microspore colchicine treatment in vitro and ploidy determination by flow cytometry. Plant Breed. 124: 511-513. 
Zenkteler M. (1971) In vitro production of haploid plants from pollen grains of Atropa belladonna L. Experientia 27: 1087.

Zenkteler M. (1972) Development of embryos and seedlins from pollen grains in Lycium halimifolium Mill. in the in vitro culture. Biol. Plant. 14: 420-422.

Zhang G.Q., Zhang D.Q., Tang G.X., He Y., Zhou W.J. (2006) Plant development from microspore-derived embryos in oilseed rape as affected by chilling, desiccation and cotyledon excision. Biol. Plant. 50: 180-186.

Zhou W.J., Tang G.X., Hagberg P. (2002) Efficient production of doubled haploid plant by immediate colchicines treatment of isolated microspores in winter Brassica napus. Plant Growth Regul. 37: 185-192. 